\title{
Palaeozoic evolution of animal mouthparts
}

\author{
Christian Klug, linda Frey, Alexander Pohle, Kenneth De Baets \& Dieter Korn
}

\begin{abstract}
During the Palaeozoic, a diversification in modes of life occurred that included a wide range of predators. Major macroecological events include the Cambrian Explosion (including the Agronomic Substrate Revolution and the here introduced 'Ediacaran-Cambrian Mouthpart Armament'), the Great Ordovician Biodiversification Event, the Palaeozoic Plankton Revolution, the Siluro-Devonian Jaw Armament (newly introduced herein) and the Devonian Nekton Revolution. Here, we discuss the evolutionary advancement in oral equipment, i.e. the Palaeozoic evolution of mouthparts and jaws in a macroecological context. It appears that particularly the latest Neoproterozoic to Cambrian and the Silurian to Devonian were phases when important innovations in the evolution of oral structures occurred. $\bullet$ Key words: Gnathostomata, Cephalopoda, evolution, convergence, diversity, nekton, jaws.
\end{abstract}

Christian Klug, Linda Frey, AleXAnder Pohle, Kenneth De BAETs \& Dieter Korn 2017. Palaeozoic evolution of animal mouthparts. Bulletin of Geosciences 92(4), 511-524 (4 figures, 1 table). Czech Geological Survey, Prague. ISSN 1214-1119. Manuscript received November 10, 2016; accepted in revised form September 22, 2017; published online December 6, 2017; issued December 31, 2017.

Christian Klug, Linda Frey \& Alexander Pohle, Paläontologisches Institut und Museum, Universität Zürich, Karl Schmid-Strasse 4, 8006 Zürich, Switzerland; chklug@pim.uzh.ch, linda.frey@pim.uzh.ch, alexander.pohle@pim.uzh.ch - Kenneth De Baets, GeoZentrum Nordbayern, Fachgruppe PaläoUmwelt, Universität Erlangen, Loewenichstr. 28, 91054 Erlangen, Germany; kenneth.debaets@fau.de • Dieter Korn, Museum für Naturkunde, Leibniz-Institut für Evolutions- und Biodiversitätsforschung, Invalidenstraße 43, 10115 Berlin, Germany; dieter.korn@mfn-berlin.de

'Explosions' in the sense of evolutionary bursts attract attention. Correspondingly, explosive radiations such as the Cambrian explosion and those following the Big Five mass extinctions as well as these extinctions themselves rank among the most widely known macroecological and palaeobiodiversity-altering events of the Phanerozoic (Fig. 1). Logically, there were other ecological events and processes that fundamentally changed the biosphere, hydrosphere and atmosphere of our planet. Knowledge of such processes appears to be somewhat under-represented in the palaeobiological literature. With this review, we want to demonstrate that some slower (more gradual) evolutionary and macroecological processes may have been underestimated. Additionally, we will discuss the differences in impact between drastic short term events and more gradual and less spectacular processes of macroecological fluctuations, radiations of groups and cases of ecological replacement of large groups (Fig. 2; see, e.g. Thayer 1979, Algeo \& Scheckler 1998, Bambach 1999, Seilacher 1999, Klug et al. 2010, Roopnarine 2010, Bush \& Bambach 2011, Payne et al. 2014, Liow et al. 2015).

In addition to the Cambrian explosion and the Great Ordovician Biodiversification Event (GOBE; Harper 2006, Servais et al. 2016), several major mass extinctions altered global biodiversity during the Palaeozoic (Sepkoski 1984, 2002; Korn 2000; House 2002; Bambach et al. 2004; Lu et al. 2006; Alroy 2010a, b; Hannisdal \& Peters 2011; McGhee et al. 2013; McGhee 2014; Long et al. 2016). Classically, Palaeozoic macroecology has been assessed by trying to quantify changes in palaeobiodiversity (Fig. 1). Still, one of the big challenges is to overcome the effects of biases in these data (e.g. Signor \& Lipps 1982; Alroy 2010a, b; Smith et al. 2012) or the link between diversity and functional disparity. The main issues are likely great differences in sampling, the inhomogeneous rock record and the incompleteness of the fossil record. Functional diversity and disparity might be more appropriate measures, although not always easy to obtain, particularly for extinct invertebrates.

Inclusion of detailed diversity analyses of single groups carried out by experts and evaluating palaeoecological or morphological information has improved our ability to develop hypotheses about major macroecological changes in the marine realm during the Palaeozoic (e.g. Signor \& Brett 1984; Vermeij 1977, 1994; Brett 2003; Nützel \& Frýda 2003; Nützel et al. 2007; Klug et al. 2010, 2015a; Servais et al. 2016). For example, the occupation of the water column by nektonic metazoans began already in the Cambrian 
(Rigby \& Milsom 2000, Butterfield 2001), but the nekton became important only in the Silurian and even more so in the Devonian, at the cost of large planktonic organisms (Bambach 1999; Kröger 2005; Klug et al. 2010, 2015a; Dahl et al. 2011). We have dubbed this process the Devonian Nekton Revolution (Fig. 2). It is strongly linked with the rise of predatory jawed vertebrates, which also became more active swimmers in the same interval (from demersal to nektonic; see also Anderson et al. 2011). The relationships between locomotion properties (motility), feeding strategies (predation) and required mouthparts and their influence on marine diversity will also be addressed in this article.

As far as diversity is concerned, the Cambrian explosion cannot be fully separated from the GOBE (Servais et al. 2008, 2009, 2016); both really belong to one giant diversification cycle, interrupted by extinctions in the Cambrian and Ordovician, and subsequently followed by a (somewhat fluctuating) plateau until the Devonian and a decline that started with the Late Devonian climatic changes and mass extinctions and, depending on author and method, a diversity spike in the Permian (e.g. Sepkoski 1978, Alroy 2010b, Smith et al. 2012).

Also, looking at earlier summaries of diversity trends for the Phanerozoic (Fig. 1) like those of Valentine (1969) or Sepkoski (1978), the end-Permian extinction could also be called the late-Palaeozoic mass extinction, as the palaeobiodiversity decrease started already in the Late Devonian and climaxed at the end of the Permian. This idea of a prolonged late Palaeozoic decline is also supported by 'dead clades walking' (Jablonski 2001), such as the trilobites and pterygotid eurypterids, which both continued with a very low (i.e. strongly reduced) diversity and disparity after the Hangenberg Event (end-Devonian; e.g. Brauckmann et al. 1993; Korn 1993, 2000; Adrain et al. 1998; Lamsdell \& Braddy 2010; Klug et al. 2015a, 2016; Korn et al. 2004, 2015). Recent diversity analyses (e.g. Korn et al. 2004, Stanley 2007, Alroy 2010b, Smith et al. 2012), however, show a moderately low diversity plateau from the Late Devonian well into the Permian, ending in a diversity maximum in the middle of the Permian. The moderate diversity of the Late Palaeozoic is classically explained by the Carboniferous to early Permian ice age (e.g. Stanley 2007).

It is commonly accepted that abiotic influences (meteorite impacts, volcanism, plate tectonics, climate including sea-level changes) as well as biotic factors influence marine diversity. In this article, we focus on biotic processes, such as radiations of groups and the potential importance of evolutionary novelties, including development of new organs, as well as the associated ecological properties. Accordingly, we address the questions of (i) when mouthparts and jaws in major groups of organisms originated, (ii) the timing of the evolution of metazoan mouthparts during the
Palaeozoic, and (iii) how benthic diversification enabled the stepwise success of various levels of predators.

\section{Material, Definitions and Methods}

In addition to published diversity curves, we used published phylogenetic reconstructions, which were based on phylogenetic analyses (Halanych 2004, Paxton 2009, Kröger et al. 2011, Parry et al. 2014, Brazeau \& Friedman 2015). We partially simplified the published phylogenies by limiting the displayed clades to those relevant to the present paper.

Various rigid, articulated structures that function to grasp, manipulate, and process food at the entrance of the animal's alimentary canal could be defined as jaws sensu lato (Hochberg et al. 2015). Research has particularly focused on vertebrates and arthropods but various other invertebrate groups also possess such structures (Hochberg et al. 2015, Uyeno \& Clark 2015). We will herein concentrate on animal groups with a reasonable fossil record.

For our purposes, we differentiate between 'mouthparts' and 'jaws' sensu stricto. 'Mouthparts' refers to either radially or linearly (vertically or horizontally) arranged hardened cuticular, sclerotic or mineralized structures in the feeding apparatus (either surrounding the mouth externally or lying directly inside the oral cavity), which consist of one part ('jaws' of the Monoplacophora, Gastropoda), where they are accompanied by radulae or more than two functional units (as in the Annelida, Conodonta, Echinoidea or Radiodonta), where they are neighboured by additional mouthparts (as in the Mandibulata) or move horizontally (as in the Chelicerata). Most of these mouthparts can only process smaller food particles, in relation to body size, than jaws.

Jaws open vertically and consist of two articulated functional units (upper and lower jaw) as in the Gnathostomata and crowngroup Cephalopoda surrounding the mouth. Each of the two units can consist of one (cephalopods) or more hard parts (vertebrates). Although jaws function quite differently in cephalopods than they do in vertebrates (see Uyeno \& Kier 2005, 2007; Uyeno \& Clark 2015), they might still have made it possible to attack more tough and elusive prey in conjunction with their tentacles. Suction feeding is an important innovation of jawed vertebrates to draw mobile or elusive prey into the oral cavity (e.g. Mallat 1996, Anderson \& Westneat 2007, Wainwright et al. 2015). In cephalopods, arms might perform this function - although these have so far not been reported from fossil externally shelled cephalopods (Ritterbush et al. 2014, Clements et al. 2017).

Dimensions of mouth parts and jaws are given in Table 1. Note that the structures herein identified as "jaws" included here always exhibits a width to body length ratios $>0.1$, while those structures here dubbed "mouthparts" 
have ratios below 0.1 . In turn, this corroborates the hypothesis that jaws permitted the ingestion of larger food items.

\section{Results and Discussion}

\section{What was the timing of the evolution of metazoan mouthparts?}

Particularly the less heavily sclerotized or mineralized mouthparts, jaw-like structures and jaws have a reduced likelihood of preservation and thus suffer from the incompleteness of the fossil record. Bengtson (2002) as well as Bengtson \& Yue (1992) discussed various steps in the evolution of predation in the Proterozoic organisms. Although fossilized mouthparts are normally missing, Neoproterozoic traces, such as boreholes in the conchs of members of the Cloudina-Namacalathus assemblage and radula traces (Radulichnus, e.g. Seilacher et al. 2003, Buatois et al. 2014) are documents of the earliest known macroscopic cases of predation. The radula traces were potentially produced by radulae of the stem-group mollusc or lophotrochozoan Kimberella. The oldest radula was described by Butterfield (2008) from the lower Cambrian Mahto Formation (Canada).

Mouthparts undoubtedly evolved independently in various groups and in very different non-homologous ways (Hochberg et al. 2015, Uyeno \& Clark 2015). As far as ecdysozoans are concerned, sclerotized mouthparts have been recorded from the early Cambrian in several groups. For example, early chaetognath mouthpart remains have been documented from the Chengjiang biota (Vannier et al. 2007) and arthropods with mouthparts are quite well-known from various Cambrian Fossillagerstätten (e.g. Conway Morris 1985, Forchielli et al. 2014). By contrast, the pentameral mouthparts of echinoids originated somewhat later, in the Ordovician (e.g. Reich \& Smith 2009). Annelid mouthparts (scolecodonts) are known from the late Cambrian and diversified rapidly in the Ordovician (Hints \& Eriksson 2007, Paxton 2009), but their early evolutionary history is still poorly constrained. Phosphatic mouthparts of conodonts first appeared in the early Cambrian.

Bipartite jaws evolved from much less sclerotized precursors independently and in some respects at least convergently if not in parallel (for a discussion of parallel

Figure 1. A short history of marine metazoan diversity in the Phanerozoic. Note that all curves share the Cambro-Ordovician diversification, the declines following the biggest mass extinctions, and the mid-Palaeozoic diversity climax (data and curves from Valentine 1969; Sepkoski 1978; Alroy 2004, 2010b; Smith et al. 2012). The most important mass extinctions are marked in red.

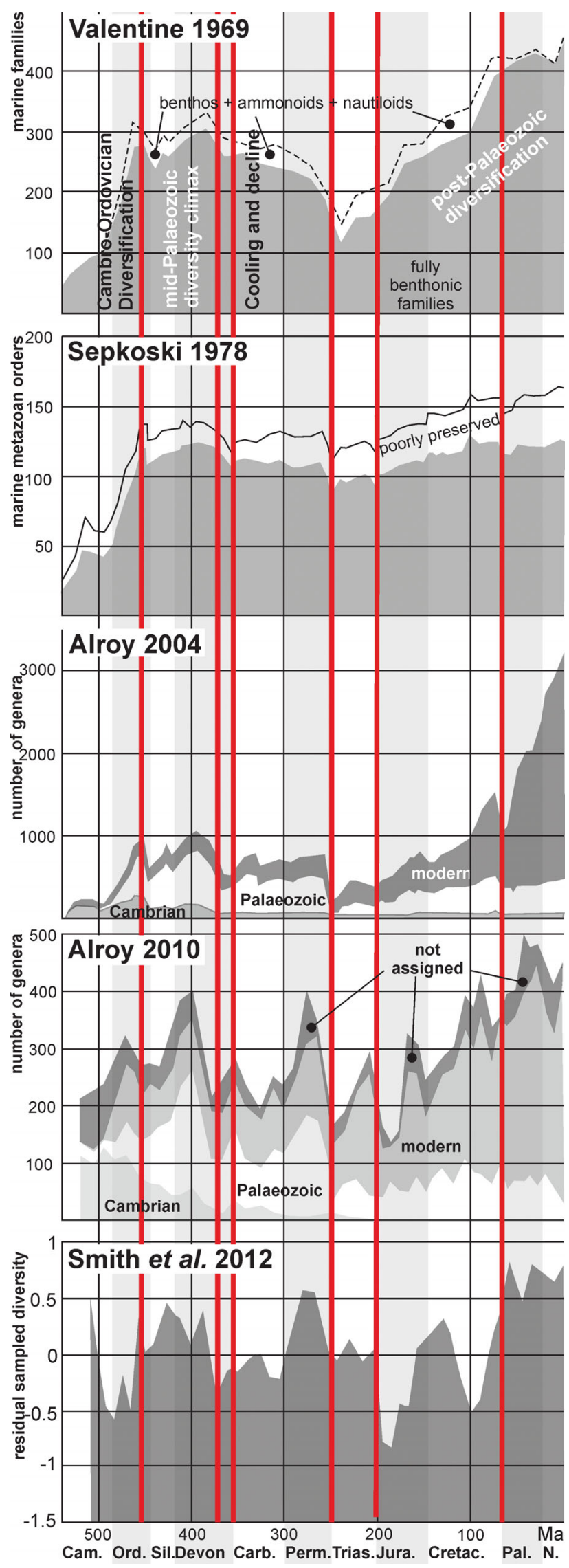


Table 1. Proportions of mouth parts and jaws in various vertebrates and invertebrates. Uncertain values are printed in bold.

\begin{tabular}{|c|c|c|c|c|c|c|c|c|c|}
\hline Systematics & Species & width & length & width/ length & body size & number & length/size & Vert. & Source \\
\hline Monoplac. & Neopilina galatheae & 2.5 & 1.5 & 0.6 & 28.5 & 1 & 0.053 & 1 & Lemche \& Wingstrand (1959) \\
\hline Gastropoda & Testudinalia tesulata & 2.2 & 1.4 & 0.63 & 18 & 1 & 0.078 & 1 & Vortsepneva et al. (2013) \\
\hline Echinodermata & Rhenechinus hopstaetteri & 2 & 4 & 2 & 42 & 10 & 0.095 & 0.5 & Smith et al. (2013) \\
\hline Malacostraca & Nahecaris jannae & 0.9 & 1.5 & 1.67 & 70 & 2 & 0.021 & 0 & Klug et al. (2008) \\
\hline Merostomata & Hughmilleria socialis & 5 & 13 & 2.6 & 220 & 2 & 0.059 & 0 & Clarke (1912) \\
\hline Merostomata & Limulus polyphemus & 3 & 12 & 4 & 210 & 2 & 0.057 & 0 & own data \\
\hline Placodermi & Qilinyu rostrata & 51 & 9 & 0.18 & 400 & 2 & 0.023 & 1 & Zhu et al. (2016) \\
\hline Placodermi & Guiyu & 40 & 45 & 1.13 & 310 & 2 & 0.145 & 1 & Zhu et al. (2009) \\
\hline Chondrichthyes & Cladoselache & 70 & 160 & 2.29 & 1120 & 2 & 0.143 & 1 & own data \\
\hline Cephalopoda & Manticoceras orbiculum & 4.2 & 3.4 & 0.81 & 10.5 & 2 & 0.324 & 1 & Clausen (1969) \\
\hline Cephalopoda & Postclymenia evoluta & 6.5 & 14 & 2.15 & 35 & 2 & 0.4 & 1 & Klug et al. (2016) \\
\hline
\end{tabular}

evolution see Monnet et al. 2011) in early jawed vertebrates and early cephalopods. The fossil record is too poor to test these lineages for parallelism, because the less sclerotized or mineralized structures are missing and the exact timing of evolutionary events is unknown. However, convergence and parallelism in unrelated lineages are unlikely to occur in random groups with no ecological connection or functional similarity. This likely correlation leads to further questions discussed below.

\section{When did jaws originate in vertebrates?}

The origin of vertebrate jaws and teeth as well as their evolutionary implications have recently received a good deal of attention (e.g. Anderson et al. 2011, Rücklin et al. 2012, Brazeau \& Friedman 2015, Chen et al. 2016, Zhu et al. 2016). In the past decades, the fossil record of gnathostomes has been extended backwards in time into the Ludlow Epoch (Silurian) with the discoveries of stem gnathostomes like Entelognathus and Quilinyu, as well as stem osteichthyans like Guiyu (Zhu et al. 1999, 2009). According to the phylogeny proposed in Brazeau \& Friedman (2015), these facts point at an origin of gnathostomes and thus jaws before the Ludlow Epoch.

Remarkably, there appears to be an - at least superficial convergence or even parallelism in the evolutionary transition from circum-oral reinforcements like the mouthparts in gastropods and monoplacophorans or cartilaginous structures in agnathans (e.g. Janvier 1996, 2007, Donoghue \& Sansom 2002, Schilling 2003, Goudemand et al. 2011) to much more strongly mineralized or sclerotized jaws in cephalopods and gnathostomes, although the question as to whether or not these structures are necessarily homologous in agnathans and gnathostomes remains open. As in early mollusc evolution, the evolutionary increase in mouth reinforcement begins with cartilaginous structures or other non-mineralized supports,carrying tooth-like structures in jawless vertebrates including conodonts sensu lato (protoconodonts; Missarzhevskij 1973, Bengtson 2002, Goudemand et al. 2011, Murdock et al. 2013). In both Mollusca and early Vertebrata, these jaw-precursors (possibly non-homologous cartilaginous or chitinous-scleroproteinaceous structures) have a low likelihood of preservation and thus are absent from the pre-Silurian fossil record, although their presence is likely, based on the extant phylogenetic brackets (Witmer 1995).

The slow increase in mouthpart reinforcement from the Cambrian to fully evolved gnathostomes in the Silurian might make it difficult to draw a clear line from jawless to jawed fish; newly discovered fossils show transitional stages in initial jaw evolution. Due to the lack of older fossil evidence and using current phylogenetic hypotheses, we suggest that the origin of vertebrate jaws occurred more or less shortly before cephalopod jaws sometime in the early Silurian (or even in the Ordovician; e.g. Sansom \& Smith 2001, Andreev et al. 2016).

\section{When did jaws originate in cephalopods?}

This question was briefly addressed by Kröger et al. (2011). They suggested that jaws are limited to the cephalopod crowngroup. This interpretation is somewhat supported by the current fossil record of cephalopod jaws, which does not extend into strata older than the Late Devonian (Matern 1931; Clausen 1969; Mapes 1987; Tanabe et al. 2015; Klug et al. 2015b, 2016). There is only one older (Silurian) record of non-conch hard parts from the apertural region of cephalopods, namely Aptychopsis. This structure is composed of three components and was first described by Barrande (1872) and later convincingly re-interpreted by Turek (1978) and Holland et al. (1978) as cephalopod opercula. So far, the oldest unequivocal cephalopod jaws were recorded by Trauth (1927-1936) and Clausen (1969) from Frasnian strata of Germany (see also 
Frye \& Feldmann 1991). They belong to gephuroceratid ammonoids. Recently, we described new discoveries from the latest Famennian of Morocco, documenting jaws from three additional important clades of Devonian ammonoids (Klug et al. 2016). Combining this information, it appears most parsimonious to assume that all ammonoids possessed jaws, including the earliest forms from the Emsian.

Here, the earliest presence of jaws or mouthparts, respectively, is inferred primarily from fossil occurrences and secondarily, in the case of cephalopods and vertebrates, from phylogenetic bracketing (Witmer 1995). In terms of mollusc jaws, the picture is blurred. Polyplacophorans and bivalves lack jaws (e.g. Vortsepneva et al. 2014), while jaw-like structures are present in monoplacophorans (Lemche \& Wingstrand 1959), gastropods (e.g. Boletzky 2007; Vortsepneva et al. 2013, 2014) and all Recent cephalopods (e.g. Boletzky 2007). An essential question is whether these structures are homologous. In gastropods and monoplacophorans, the chitinous-scleroproteinaceous structures oppose the radula, i.e. they represent some kind of upper jaw and thus might be homologous to the upper jaw in cephalopods. As far as the lower jaw is concerned, the situation is less clear: Boletzky (2007) stated that the "evolutionary origin of the lower jaw, which has no obvious homologue in other molluscs, remains a matter of debate". In any case, it appears reasonable that at least some kind of precursor or 'Anlagen' of jaws were present in the common ancestors of cephalopods, monoplacophorans and gastropods.

But why are cephalopod jaws absent from strata older than the Late Devonian? Answering this question becomes even more difficult in light of the fact that cephalopod radulae are known from the Late Ordovician Soom Shale Lagerstätte (South Africa; Gabbott 1999) and the Silurian Kirusillas Shale (Bolivia; Mehl 1984). Their general scarcity and the absence of cephalopod radulae between the $\mathrm{Si}$ lurian and the Carboniferous (e.g. Closs 1960, 1967), however, underscores the incompleteness of the fossil record (Kruta \& Tanabe 2015). In turn, this incompleteness suggests that the presence of the chitin and scleroproteins in "jaws" of monoplacophorans and gastropods on the one hand and pre-Frasnian cephalopods on the other hand was the reason for its non-preservation. In other words, it appears that jaw-like structures were already present in the

Figure 2. The respective roles of plankton versus nekton (A), energy-need in predators (B), diversity of 'durophagous' animals (C) and diversity/size of eurypterines versus arthrodires throughout the Palaeozoic (D). Data and curves from Signor \& Brett (1984), Bambach (1999), Klug et al. (2010) and Lamsdell \& Braddy (2010). Numbers in D correspond to taxon names: 1 - Erettopterus; 2 - Pterygotus; 3 - Acutiramus; 4 -Jaekelopterus; 5 -Arctolepis; 6 - Eastmanosteus; 7 -Dunkleosteus.

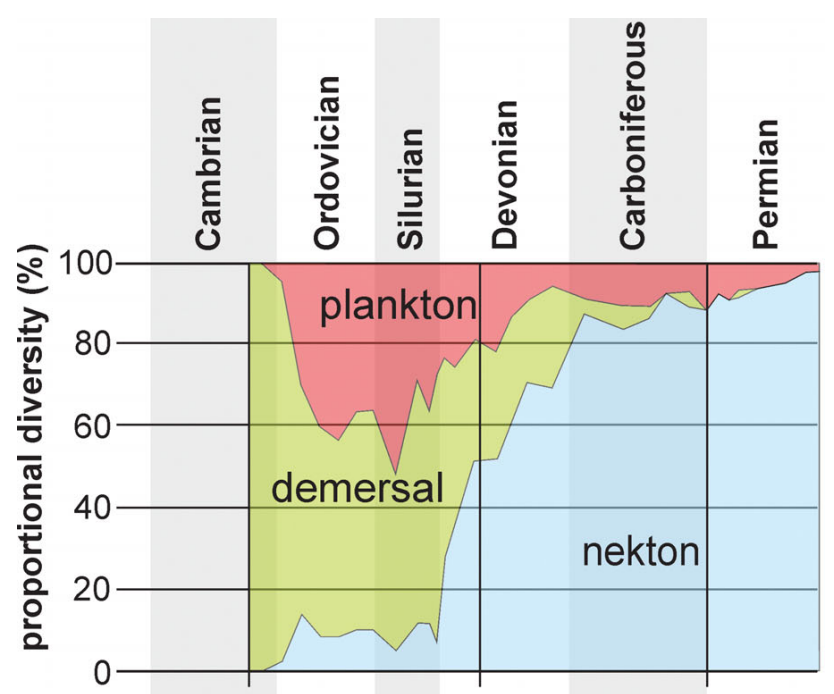

A After Klug et al. (2010)

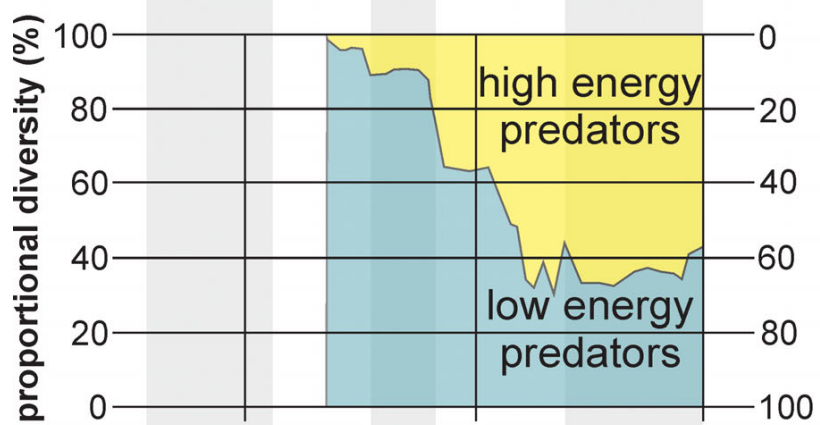

B After Bambach (1999)

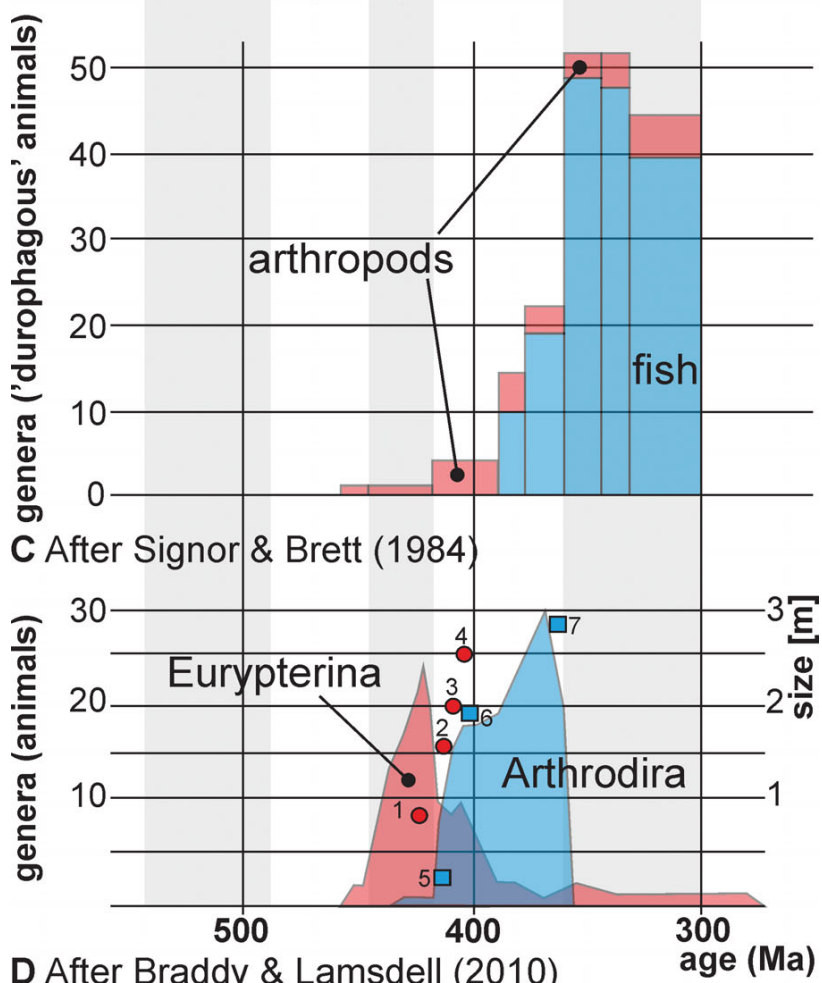

D After Braddy \& Lamsdell (2010) 
first cephalopods (as indicated by the extant phylogenetic bracket between Neopilina and Recent cephalopods; e.g. Clausen 1969; Vortsepneva et al. 2013, 2014) but initially with a much 'weaker' chitin and scleroproteins (thinner and maybe less resistant) with a lower preservation potential than the beaks in crown group cephalopods (Kear et al. 1995). Extant cephalopods jaws are made of one of the hardest and stiffest known wholly organic materials (Miserez et al. 2008), which probably applied to many extinct cephalopods as well. Slightly elevated structures in the Ordovician orthocones published by Gabbott (1999) might be homologous to jaws of later cephalopods; at least superficially, these structures are reminiscent of the narrow "jaws" of gastropods. A re-examination of these materials might shed more light on this issue. The lack of jaws is even more peculiar as large orthoconic nautiloids have often been interpreted as 'durophagous' predators (Brett \& Walker 2002). Large paired injuries in Ordovician nautiloids might have been caused by shell-breaking predators including nautiloids and eurypterids (Kröger 2005), although the culprits are hard to pin down (Kröger 2005, 2011).

Taking these observations and inferences together, it appears that jaws evolved from weakly sclerotized structures in early molluscs to the tough chitinous-scleroproteinaceous cephalopod beaks, of which Frasnian to Recent records are known. This slow evolutionary increase in jaw reinforcement by chitin and scleroproteins appears to parallel the evolutionary change in mouthparts sensu latu of, e.g. ecdysozoans and vertebrates. We place the origin of cephalopod jaws quite conservatively in the late Silurian because the phylogenetic bracket combined with good fossil evidence points at that age (Fig. 3).

\section{How was the Palaeozoic benthic diversification linked with the evolution of various levels of predators?}

Overall, the long-term evolution of life on our planet has been characterized by an increasing occupation of habitats until their saturation, followed (or accompanied) by the conquest of new habitats and novel modes of life. Assuming that the origin of life includes the initial formation of cells near the water surface or around black smokers, life would have begun either as planktonic or benthic to demersal prokaryotic cells; 'soon' thereafter, the sessile benthic mode of life, including eukaryotic algae appeared and spread over the global oceans (e.g. Signor \& Vermeij 1994, Schopf et al. 2007). In the Neoproterozoic, multicellular organisms added motile benthic modes of life including the first macroscopic predators in a broad sense (review in Bengtson 2002; see also Kelley et al. 2003). Thus, after a very long phase of Proterozoic prokaryote 'peace' (see
Porter 2016 for a different view), the escalation of the ongoing predatory arms race had begun.

During the Neoproterozoic, macroscopic life was largely limited to benthic habitats (e.g. Seilacher 1999); skeletons and sclerotized mouthparts began to evolve toward the end of this era. With the Cambrian success of protective skeletons (Cambrian explosion, e.g. Valentine et al. 1999), mouthparts experienced a positive selection for reinforcement, i.e. more strongly sclerotized or even mineralized mouthparts. An increase in motility, the reinforcement of defensive skeletal structures or the choice of an infaunal life habit ('Agronomic substrate revolution'; Seilacher \& Pflüger 1994) were probably the main evolutionary responses to the rising predatory pressure. In turn, these changes led to a higher energy requirement as the predators themselves had to actually chase, catch, and kill their prey, to break the increasingly resistant protective skeletons or to dig them out of the sediment. On the one hand, prey animals were forced to escape into new habitats or behaviours, often increasing energetic requirements, or a greater investment in defence (Signor \& Brett 1984; Bambach 1993, 1999; Brett \& Walker 2002; Brett 2003); on the other hand, predators of most levels had to invest more energy in catching prey, overcoming the new defensive structures or excavating endobenthos (Fig. 2B). In the light of this escalatory process, it is not surprising that large demersal or even nektonic predators, as well as large filter feeders, had already evolved in the Cambrian (e.g. Whittington \& Briggs 1985, Harvey \& Butterfield 2008, Daley et al. 2013, Vinther et al. 2014, Van Roy et al. 2015). This arms race could proceed only by producing ever more efficient mouthparts and locomotory structures, dealing in different ways with the trade-offs between investment in these structures and physical efforts on the one side and the greater predation success on the other.

Similar conclusions were drawn by Brett \& Walker (2002). According to them, several 'durophagous' groups (sensu latu, i.e. including a broad range of animals feeding on prey with hard skeletons) originated or radiated around the Mid-Palaeozoic (see Fig. 4) including cephalopods (e.g. ammonoids), crustaceans (phyllocarids, decapods and stomatopods) and jawed fish (Brett \&Walker 2002). The radiation of phyllocarids had already started in the Early Palaeozoic (Collette \& Hagadorn 2010). Cambrian anomalocaridids (Conway Morris \& Jenkins 1985, Nedin 1999) as well as other basal arthropods like Sidneyia (Briggs et al. 1994) or Utahcaris (Conway-Morris \& Robison 1986), possibly a basal chelicerate (Legg \& Pates 2016), have occasionally been interpreted to be 'durophagous' predators (see also Conway Morris \& Jenkins 1985) based on gut contents or more indirectly based on attributed coprolites or injuries in their prey, but this might only be true for some species like Anomalocaris canadensis (Daley et al. 2013), while some other Cambrian 


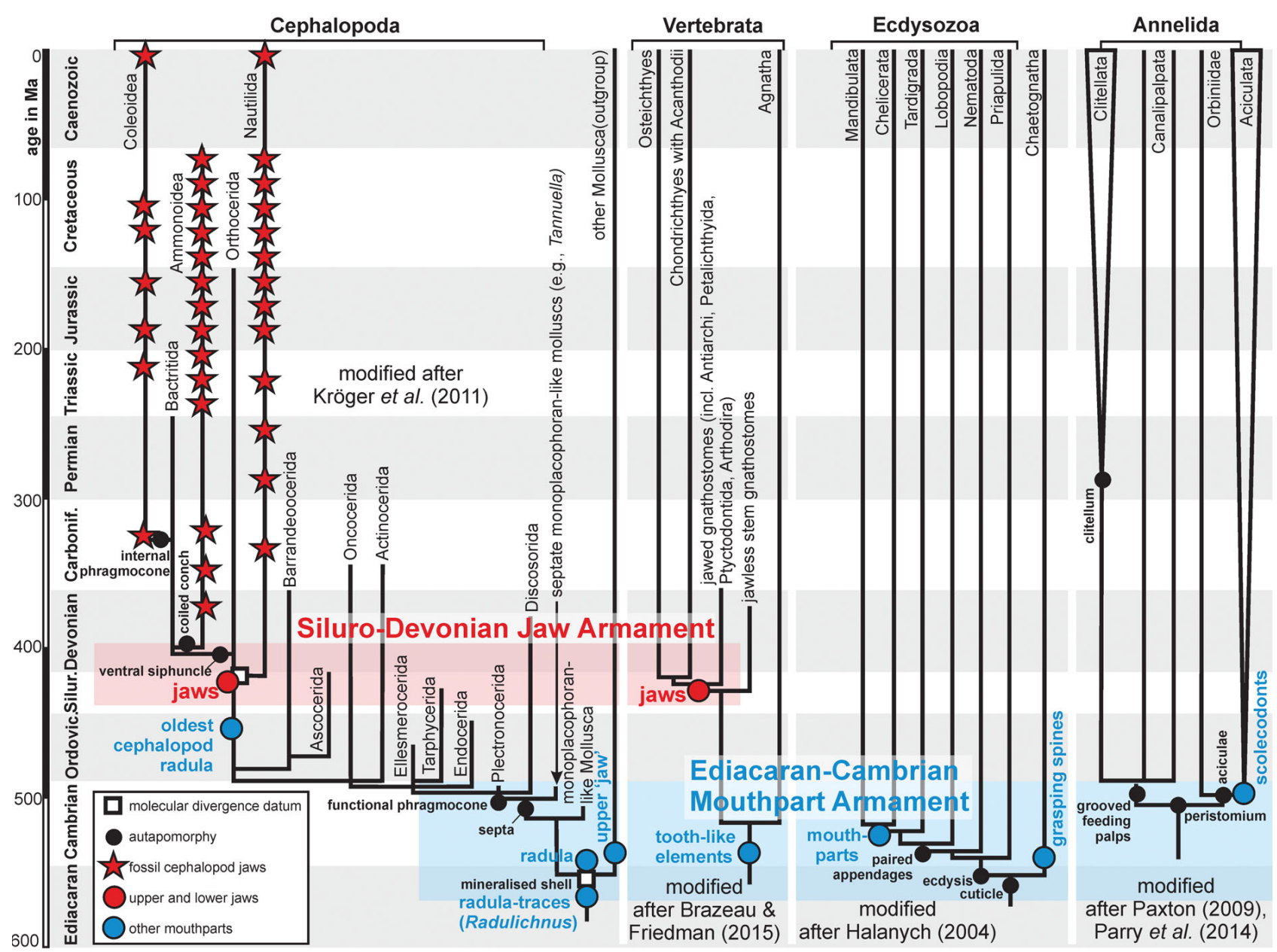

Figure 3. Cephalopod, vertebrate and ecdysozoan diversity with the origins of mouthparts and jaws. Note that many mouthparts evolved in the Cambrian, others in the Ordovician (some are not illustrated here, e.g. echinoid mouth parts). Interestingly, jaws (including an upper and a lower element) appear to have evolved in the Silurian both in cephalopods and in fish. Simplified cladograms based on Halanych (2004), Paxton (2009), Kröger et al. (2011), Parry et al. (2014) and Brazeau \& Friedman (2015).

and Ordovician anomalocaridids were filter feeders (Vinther et al. 2014, Van Roy et al. 2015). It is more likely that anomalocaridids were mostly feeding on weakly sclerotized arthropods and other soft-bodied prey. Eurypterids are known from the Ordovician until the Permian (Tetlie 2007), but many were marginal marine. The predatory marine eurypterids (Eurypterina) diversified from the Ordovician to the Siluro-Devonian where some nektonic pterygotids reached gigantic sizes (Braddy et al. 2008, Lamsdell \& Braddy 2010, Klug et al. 2015a). Eurypterina diversity waned during the Devonian, possibly because they were out-competed by jawed fishes and other predators (Fig. 2D; Lamsdell \& Braddy 2010). The only known "jawed" annelids are eunicids and phyllodocids, which are closely related based on morphological and molecular evidence (see Parry et al. 2014 for a review). The earliest phosphatic annelid mouthparts (scolecodonts) are known from the late Cambrian strata and the Annelida radiated in the Ordovician (Hints \& Eriksson 2007, Paxton
2009). Some extant annelids like bobbit worms (Eunice aphroditois) are vicious predators capable of cutting their prey (including fishes) in half. Mouthparts of bobbit worms used in raptorial feeding are known since the Devonian (Eriksson et al. 2017), but their feeding ecology is still unclear. Stem-group annelids lack phosphatic mouthparts, indicating that these only evolved later - although they probably had an eversible pharynx (Parry et al. 2014). Conodonts with multi-element apparatuses with phosphatic elements first appeared in the Cambrian, although their architecture varies widely and their feeding mode poorly is constrained (e.g. Martínez-Pérez et al. 2016).

The repeated macroecological 'resets' that occurred due to mass extinctions of varying intensity freed the ecospace, especially at the level of larger predators. Possibly, it is this interplay between extinctions and arms races that allowed the evolution of ever more sophisticated and thus more efficient (but possibly more expensive from an 


\begin{tabular}{|c|c|c|c|c|c|c|}
\hline $\begin{array}{l}\text { Main taxa of } \\
\text { 'durophagous' predators }\end{array}$ & rs Cambrian & Ordovician & Silurian & Devonian & Carboniferous & Permian \\
\hline \multicolumn{7}{|l|}{ priapulids } \\
\hline \multicolumn{7}{|c|}{$\begin{array}{l}\text { Sidneyia }+ \\
\text { closely related taxa } \sigma\end{array}$} \\
\hline anomalocaridids & 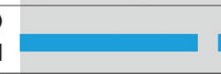 & 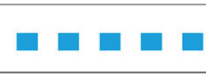 & a & $\square$ & & \\
\hline phyllocarids & & I $\square=\square$ & m & & 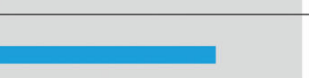 & \\
\hline eurypterids & $\begin{array}{l}\text { coliacar } \\
\text { cambri }\end{array}$ & $\square$ & & 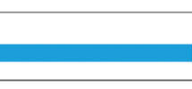 & ㅁロ・ロロロ & \\
\hline decapods & Mouthp & & & a & Iோロ日ロ & 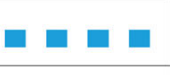 \\
\hline stomatopods & Arrname & & & & 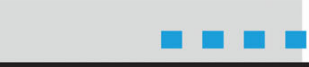 & $\square=\square$ \\
\hline nautiloids & & 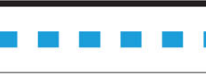 & 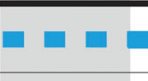 & & & a \\
\hline ammonoids & & Sil & ro= & 다 & & \\
\hline placoderms & & Dev & nían & & & \\
\hline sharks & & $J$ & W & & & \\
\hline basal actinopterygian & & & & & & \\
\hline
\end{tabular}

Figure 4. Ranges of major groups of Palaeozoic 'durophagous' predators (updated and modified from Brett \& Walker 2002). Thin lines - present, but minor; thick lines - abundant; broken lines - possibly present but rare or difficult to interpret. Jawed groups in red. Abbreviations: Vert. - Vertebra; Loph. - Lophotrochozoa.

energetic point of view) locomotory and feeding apparatuses. Among meso- to macro-predators, a positive selection therefore occurred towards an increase in mobility (Devonian Nekton Revolution; Klug et al. 2010) as well as larger and stronger oral instruments (this paper). For the two main phases of mouthpart and jaw formation, we suggest the terms Ediacaran-Cambrian Mouthpart Armament and Siluro-Devonian Jaw Armament (Fig. 4; compare, e.g. Brett \& Walker 2002, Anderson et al. 2011). A greater mobility at reasonable energetic costs was achieved by, e.g. reinforced axial skeletons and reduced body armor in vertebrates as well as tightly coiled conchs (much later also internalized or reduced) in cephalopods (e.g. Klug \& Korn 2004, Kröger et al. 2011, Naglik et al. 2015).

As far as the evolution of jaws in cephalopods and vertebrates is concerned, we hypothesize the following scenario (taking into account the incompleteness of the fossil record and limitations in functional interpretations). In both groups, poorly sclerotized and mineralized supporting structures existed around the mouth even in Cambrian representatives, indicating that some mechanical stress was involved in the feeding process, thus hinting at a predatory mode of life. Enhancement of defensive structures in prey organisms (Signor \& Brett 1984) caused a positive selection for an oral rearmament.

From the fossil record, it appears that this rearmament occurred at around the same time, though maybe somewhat earlier in vertebrates than in cephalopods. This proximity in the appearance of a functionally similar structure in two phylogenetically independent groups is suggestive of an ecological link. Nevertheless, suction feeding in cephalopods is probably limited, which instead used their arms to get prey close to their mouths. Despite the fact that jaws function quite differently in cephalopods and vertebrates, they might still have allowed both groups to attack larger or more robust prey. Accordingly, we propose the following hypotheses and discuss them:

(1) Null hypothesis: The temporal correlation is pure coincidence; an ecological link does not exist.

This lack of connection appears unlikely, because Siluro-Devonian gnathostomes and cephalopods occurred in the same habitats, both likely occupied a range of water depths, both were predators of strongly varying size and both likely used all available metazoan food sources. Therefore, a strong ecological overlap (diet, geographic distribution, water depth, motility etc.) is highly likely.

(2) The food sources of cephalopods were always largely different from those of fishes and thus these changes occurred completely independently.

This hypothesis appears unlikely because both cephalopods and gnathostomes occupy a broad range of marine habitats today and also have a broad range of food sources, which partially overlap. One observation from Recent ecosystems is that, for example, in pelagic habitats that have 
been overfished for predatory fish (tuna, sharks), the large Humboldt squid Dosidicus gigas becomes more abundant and appears to adopt the role of the large gnathostomes (Zeidberg \& Robinson 2007).

(3) The evolution of gnathostomes increased the predatory pressure causing a further enhancement in defensive structures (e.g. spinosity in arthropods and crinoids). In order to maintain access to these food sources, a positive selection for stronger mouthparts fostered the evolution of reinforced cephalopod jaws.

During the Silurian and Devonian interval, productivity increased, probably caused by the increaed release of nutrients from soil by rooted land plants and rising input of terrestrially derived organic matter (Algeo \& Scheckler 1998). This increase in nutrient supply created a general boost in marine diversity following the Late Ordovician extinction (Fig. 1) and thus also in potential prey for gnathostomes and cephalopods. Reciprocal feedbacks between prey and their defence structures, e.g. in arthropods and echinoderms (see for example Reich \& Smith 2009) and either group of competing jawed predators (and increasing efficiency of both locomotory structures and jaws), appear quite likely ( $c f$. Vermeij 1987, 1994, 2013; Brett \& Walker 2002).

(4) Cephalopods evolved jaws earlier, but the preservation potential is lower and thus, the fossil record shows an inaccurate pattern.

The preservation potential of chitin and scleroproteins is lower than that of bone and thus this possibility cannot be ruled out. Nevertheless, it does not falsify the hypothesis of escalatory feedbacks between gnathostomes, cephalopods, and prey organisms. Furthermore, in rare Ordovician and Silurian orthoconic nautiloids with preserved chitinous radulae, jaw-like structures are not preserved in sufficient quality to permit unequivocal interpretation.

\section{Conclusions}

Macroecological changes during the Palaeozoic are reflected in diversity fluctuations. Some of these changes have abiotic causes, but some were also induced by biotic processes such as major evolutionary innovations that profoundly impacted marine ecosystems. Here, we discuss the evolution of invertebrate mouthparts as well as jaws of cephalopods and vertebrates in the light of macroecological changes. Although the fossil record is quite incomplete, hampering the identification of the exact time of origin of these structures, it appears that invertebrate mouthparts mainly evolved in the late Proterozoic and early Cambrian, while the jaws of cephalopods and vertebrates appeared probably in the Silurian (based on fossils and phylogenetic bracketing). Current evidence suggests that the jaws of vertebrates evolved before those of cephalopods. Independent of the sequence of these evolutionary events, it appears likely that the rise of jawed animals increased predatory pressure on prey organisms. In turn, the evolution of enhanced defensive structures potentially caused a positive selection for reinforced jaws in the other group (reciprocal selection; Vermeij 2013). Using Vermeij's terminology (Vermeij 1987, 1994), vertebrates would be the 'predators', cephalopods the 'competitors', and other invertebrates the 'dangerous prey'.

The evolution and radiation of jawed metazoans makes sense in the context of the increasing nutrient availability due to the spread of land plants, which likely fostered increased productivity of marine life to varying degrees (though it was likely detrimental in the Late Devonian, where it led to black shale deposition and extinctions). This increase in nutrients implies that energy was available for the addition of new trophic levels, providing ecospace for the evolution of new groups of predators. Reciprocal feedbacks between the two main groups of jawed metazoans and invertebrate prey are here suggested to have been an important evolutionary feedback loop of the Middle Palaeozoic (Brett \& Walker 2002, Vermeij 2013). For the initial phase of evolution of mouthparts, we suggest the term Ediacaran-Cambrian Mouthpart Armament and for the later (Middle Palaeozoic) reinforcement, we coin the term Siluro-Devonian Jaw Armament. Much more research on the origin, functional disparity and biomechanics of these structures is needed, particularly in invertebrates, to test their evolutionary relevance and degree of convergence.

\section{Acknowledgements}

We thank the Swiss National Science Foundation for financial support of our ongoing research projects (Project Numbers 200021_156105, 200021_169627). Also, we greatly appreciate the stimulating reviews of Margret M. Yacobucci (Bowling Green), Isabelle Kruta (Paris) and an anonymous reviewer.

\section{References}

Adrain, J.M., Fortey, R.A. \& Westrop, S.R. 1998. Post-Cambrian trilobite diversity and evolutionary faunas. Science 280, 1922-1925. DOI 10.1126/science.280.5371.1922

Algeo, T.J. \& SChECKLER, S.E. 1998. Terrestrial-marine teleconnections in the Devonian: links between the evolution of land plants, weathering processes, and marine anoxic events. Philosophical Transactions of the Royal Society of London, (B): Biological Sciences 353, 113-130.

DOI 10.1098/rstb.1998.0195

AlroY, J. 2004. Are Sepkoski's evolutionary faunas dynamically coherent? Evolutionary Ecology Research 6, 1-32. 
Alroy, J. 2010a. Fair sampling of taxonomic richness and unbiased estimation of origination and extinction rates. Quantitative methods in paleobiology. Paleontoleontological Society Papers 16, 55-80.

Alroy, J. 2010b. The shifting balance of diversity among major marine animal groups. Science 329, 1191-1194. DOI 10.1126/science.1189910

Anderson, P.S.L. \& Westneat, M.W. 2007. Feeding mechanics and bite force modelling of the skull of Dunkleosteus terrelli, an ancient apex predator. Biology Letters 3, 77-80. DOI 10.1098/rsbl.2006.0569

Anderson, P.S.L., Friedman, M., Brazeau, M.D. \& Rayfield, E.J. 2011. Initial radiation of jaws demonstrated stability despite faunal and environmental change. Nature 476, 206-209. DOI 10.1038/nature10207

Andreev, P., Coates, M.I., Karatajūtè-Talimaa, V., Shelton, R.M., Cooper, P.R., Wang, N.Z. \& SAnsom, I.J. 2016. The systematics of the Mongolepidida (Chondrichthyes) and the Ordovician origins of the clade. PeerJ 4, e1850. https://peerj.com/articles/1850/DOI 10.7717/peerj.1850

BAMBACH, R.K. 1993. Seafood through time: changes in biomass, energetics, and productivity in the marine ecosystem. Paleobiology 19, 372-397. DOI 10.1017/S0094837300000336

BАмваCH, R.K. 1999. Energetics in the global marine fauna: a connection between terrestrial diversification and change in the marine biosphere. Geobios 32, 131-144. DOI 10.1016/S0016-6995(99)80025-4

Bambach, R.K., Knoll, A.H. \& Wang, S.C. 2004. Origination, extinction, and mass depletions of marine diversity. Paleobiology 30, 522-542.

DOI 10.1666/0094-8373(2004)030<0522:OEAMDO >2.0.CO;2

Barrande, J. 1872. Systême Silurien du centre de la Bohême. Ière partie: Recherches paléontologiques, Suppl. 1. 648 pp. Privately published, Prague \& Paris.

Bengtson, S. 2002. Origins and early evolution of predation. Paleontological Society Papers 8, 289-318.

Bengtson, S. \& Yue, Z. 1992. Predatorial borings in late Precambrian mineralized exoskeletons. Science 257, 367-369. DOI 10.1126/science.257.5068.367

BoletZKY, S. vON 2007. Origin of the lower jaw in cephalopods: a biting issue. Paläontologische Zeitschrift 81, 328-333. DOI 10.1007/BF02990182

Braddy, S.J., Poschmann, M. \& Tetlie, O.E. 2008. Giant claw reveals the largest ever arthropod. Biology Letters 4, 106-109. DOI 10.1098/rsbl.2007.0491

Brauckmann, C., Chlupáč, I. \& Feist, R. 1993. Trilobites at the Devonian-Carboniferous boundary. Annales de la Société géologique de Belgique 115, 507-518.

Brazeau, M.D. \& Friedman, M. 2015. The origin and early phylogenetic history of jawed vertebrates. Nature 420, 490-497. DOI 10.1038/nature1443

BRETT, C.E. 2003. Durophagous predation in Paleozoic marine benthic assemblages, 401-432. In Kelley, P., Kowalewski, M. \& Hansen, T. (eds) Predator-Prey Interactions in the Fossil Record. Kluwer Academic-Plenum Publishers.
Brett, C.E. \& Walker, S.E. 2002. Predators and predation in Paleozoic marine environments. Paleontological Society Papers 8, 93-118.

Briggs, D.E., Erwin, F.J. \& Douglas, H. 1994. The fossils of the Burgess Shale. 238 pp. Smithsonian Institution Press, Washington.

Buatois, L.A., Narbonne, G.M., Mángano, G.A., Carmona, N.B. \& Myrow, P. 2014. Ediacaran matground ecology persisted into the earliest Cambrian. Nature Communications 5, 3544. DOI $10.1038 /$ ncomms 4544

Bush, A.M. \& Bambach, R.K. 2011. Paleoecologic megatrends in marine metazoan. Annual Review of Earth and Planetary Sciences 39, 241-269.

DOI 10.1146/annurev-earth-040809-152556

BUtTERFIELD, N.J. 2001. Ecology and evolution of the Cambrian plankton, 200-216. In Zhuravlev, A.Y. \& Riding, R. (eds) The Ecology of the Cambrian Radiation. Columbia University Press, New York.

Butterfield, N.J. 2008. An early Cambrian radula. Journal of Paleontology 82, 543-554. DOI 10.1666/07-066.1

Chen, D., Blom, H., Sanchez, S., Tafforeau, P. \& Ahlberg, P.E. 2016. The stem osteichthyan Andreolepis and the origin of tooth replacement. Nature 539, 237-241. DOI 10.1038/nature19812

Clarke, J.M. 1912. The Eurypterida of New York. Vol. 2. New York State Museum Memoir 14, 1-439.

Clausen, C.D. 1969. Oberdevonische Cephalopoden aus dem Rheinischen Schiefergebirge. II.: Gephuroceratidae, Beloceratidae. Palaeontographica A 132, 95-178.

Clements, T., Colleary, C., De Baets, K. \& Vinther, J. 2017. Buoyancy mechanisms limit preservation of coleoid cephalopod soft tissues in Mesozoic lagerstätten. Palaeontology 60,1-14. DOI 10.1111/pala.12267

Closs, D. 1960. Contribuição ao estudo dos Aptychi (Cephalopoda-Ammonoidea) do Jurássico. Pôrto Alegre: Universidad do Rio Grande do Sul, Publicacão Especial 2, $1-67$.

Closs, D. 1967. Goniatiten mit Radula und Kieferapparat in der Itararé-Formation von Uruguay. Paläontologische Zeitschrift 41, 19-37. DOI 10.1007/BF02998546

Collette, J.H. \& Hagadorn, J.W. 2010. Early evolution of phyllocarid arthropods: Phylogeny and systematics of Cambrian-Devonian archaeostracans. Journal of Paleontology 84, 795-820. DOI 10.1666/09-092.1

Conway Morris, S. 1985. Cambrian Lagerstätten: their distribution and significance. Philosophical Transactions of the Royal Society of London B 311, 49-65. DOI 10.1098/rstb.1985.0138

Conway Morris, S. \& Jenkins, R. 1985. Healed injuries in early Cambrian trilobites from South Australia. Alcheringa 9, 167-177. DOI 10.1080/03115518508618965

Conway Morris, S. \& Robison, R.A. 1986. Middle Cambrian priapulids and other soft-bodied fossils from Utah and Spain. The University of Kansas Paleontological Contributions 117, $1-22$.

Dahl, T.W., Hammarlund, E.U., Anbar, A.D., Bond, D.P.G., Gill, B.C., Gordon, G.W., Knoll, A.H., Nielsen, A.T., 
Schovsbo, N.H. \& CANFIELd, D.E. 2011. Devonian rise in atmospheric oxygen correlated to the radiations of terrestrial plants and large predatory fish. PNAS 107, 17911-17915. DOI 10.1073/pnas.1011287107 http://www.pnas.org/content/107/42/17911

Daley, A.C., Paterson, J.R., Edgecombe, G.D., GarcíaBeLLIDO, D.C. \& JAGO, J.B. 2013. New anatomical information on Anomalocaris from the Cambrian Emu Bay Shale of South Australia and a reassessment of its inferred predatory habits. Palaeontology 56, 971-990. DOI $10.1111 /$ pala.12029

Donoghue, P.C.J. \& SAnsom, A.I.J. 2002. Origin and early evolution of vertebrate skeletonization. Microscopy Research and Technique 59, 352-372. DOI 10.1002/jemt.10217

Eriksson, M.E., PArry, L.A. \& Rudkin, D.M. 2017. Earth's oldest 'Bobbit worm' - gigantism in a Devonian eunicidan polychaete. Scientific Reports 7, 43061. DOI 10.1038/srep43061

Forchielli, A., Steiner, M., Kasbohm, J., Hu, S. \& Keupp, H. 2014. Taphonomic traits of clay-hosted early Cambrian Burgess Shale-type fossil Lagerstätten in South China. Palaeogeography, Palaeoclimatology, Palaeoecology 398, 59-85. DOI 10.1016/j.palaeo.2013.08.001

Frye, C.J. \& Feldmann, N.R.M. 1991. North American Late Devonian cephalopod aptychi. Kirtlandia 46, 49-71.

Gаввотт, S.E. 1999. Orthoconic cephalopods and associated fauna from the Late Ordovician Soom Shale Lagerstätte, South Africa. Palaeontology 42, 123-148.

DOI 10.1111/1475-4983.00065

Goudemand, N., Orchard, M.J., Urdy, S., Bucher, H., \& TAFFOREAU, P. 2011. Synchrotron-aided reconstruction of the conodont feeding apparatus and implications for the mouth of the first vertebrates. PNAS 108, 8720-8724.

DOI 10.1073/pnas.1101754108

Halanych, K.M. 2004. The new view of animal phylogeny. Annual Review of Ecology Evolution, and Systematics 35, 229-256. DOI 10.1146/annurev.ecolsys.35.112202.130124

Hannisdal, B. \& Peters, S.E. 2011. Phanerozoic Earth System Evolution and Marine Biodiversity. Science 334, 1121-1124. DOI 10.1126/science.1210695

Harper, D.A.T. 2006. The Ordovician biodiversification: Setting an agenda for marine life. Palaeogeography, Palaeoclimatology, Palaeoecology 232, 148-166. DOI 10.1016/j.palaeo.2005.07.010

HaRvey, T.H.P. \& Butterfield, N.J. 2008. Sophisticated particlefeeding in a large Early Cambrian crustacean. Nature 452, 868-871. DOI 10.1038/nature06724

HinTs, O. \& ERIKSSON, M.E. 2007. Diversification and biogeography of scolecodont-bearing polychaetes in the Ordovician. Palaeogeography, Palaeoclimatology, Palaeoecology 254, 95-114. DOI 10.1016/j.palaeo.2006.02.029

Hochberg, R., Wallace, R.L. \& Walsh, E.J. 2015. Soft Bodies, Hard Jaws: An Introduction to the Symposium, with Rotifers as Models of Jaw Diversity. Integrative \& Comparative Biology 55, 179-192. DOI 10.1093/icb/icv002

Holland, B., Stridsberg, S. \& Bergström, J. 1978. Confirma- tion of the reconstruction of Aptychopsis. Lethaia 11, 144. DOI 10.1111/j.1502-3931.1978.tb01299.x

House, M.R. 2002. Strength, timing, setting and cause of mid Palaeozoic extinctions. Palaeogeography, Palaeoclimatology, Palaeoecology 181, 5-25.

DOI 10.1016/S0031-0182(01)00471-0

JABLONSKI, D. 2001. Lessons from the past: Evolutionary impacts of mass extinctions. PNAS 98, 5393-5398.

DOI 10.1073/pnas.101092598

JANVIER, P. 1996. Early Vertebrates. Oxford monographs on geology and geophysics 33, 393 pp. Clarendon Press, Oxford.

JANVIER, P. 2007. Homologies and evolutionary transitions in early vertebrate history, 57-121. In ANDERson, J.S. \& SuES, H.D. (eds) Major transitions in vertebrate evolution. Indiana University Press, Bloomington.

Kear, A.J., Briggs, D.E.G. \& Donovan, D.T. 1995. Decay and fossilization of non-mineralized tissue in coleoid cephalopods. Palaeontology 38, 105-131.

Kelley, P.H., Kowalewski, M. \& Hansen, T.A. (eds) 2003. Predator-Prey Interactions in the Fossil Record. Topics in Geobiology 20, 464 pp. Plenum/Kluwer, New York. DOI 10.1007/978-1-4615-0161-9

KLUG, C. \& Korn, D. 2004. The origin of ammonoid locomotion. Acta Palaeontologica Polonica 49, 235-242.

Klug, C., De Baets, K., Kröger, B., Bell, M.A. \& Korn, D. 2015a. Normal giants? Temporal and latitudinal shifts of Palaeozoic marine invertebrate gigantism and global change. Lethaia 48, 267-288. DOI 10.1111/let.12104

Klug, C., Frey, L., Korn, D., Jattiot, R. \& RÜCKlin, M. 2016. The oldest Gondwanan cephalopod mandibles (Hangenberg Black Shale, Late Devonian) and the Mid-Palaeozoic rise of jaws. Palaeontology 59, 611-629. DOI 10.1111/pala.12248

Klug, C., Kröger, B., Kiessling, W., Mullins, G.L., Servais, T., FrÝdA, J., Korn, D. \& TuRnER, S. 2010. The Devonian nekton revolution. Lethaia 43, 465-477. DOI 10.1111/j.1502-3931.2009.00206.x

Klug, C., Kröger, B., Rücklin, M., Korn, D., Schemm-Gregory, M., De BAETS, K. \& MAPES, R.H. 2008. Ecological change during the early Emsian (Devonian) in the Tafilalt (Morocco), the origin of the Ammonoidea, and the first African pyrgocystid edrioasteroids, machaerids and phyllocarids. Palaeontographica A 283, 1-94.

DOI 10.1127/pala/283/2008/83

Klug, C., Kröger, B., Vinther, J., Fuchs, D. \& De Baets, K. 2015b. Ancestry, origin and early evolution of ammonoids, 3-24. In Klug, C., Korn, D., De Baets, K. Kruta, I. \& MAPES, R.H. (eds) Ammonoid paleobiology, Volume II: from macroevolution to paleogeography. Topics in Geobiology 44.

Korn, D. 1993. Typostrophism in Palaeozoic ammonoids? Paläontologische Zeitschrift 77, 445-470.

DOI 10.1007/BF03006953

KoRn, D. 2000. Morphospace occupation of ammonoids over the Devonian-Carboniferous boundary. Paläontologische Zeitschrift 74, 247-257. DOI 10.1007/BF02988100

Korn, D., Belka, Z., Fröhlich, S., RÜCKlin, M. \& Wendt, J. 2004. The youngest African clymeniids (Ammonoidea, Late 
Devonian) - failed survivors of the Hangenberg Event. Lethaia 37, 307-315. DOI 10.1080/00241160410002054

Korn, D., Klug, C. \& Walton, S.A. 2015. Taxonomic diversity and morphological disparity of Paleozoic ammonoids, 431-464. In Klug, C., Korn, D., De Baets, K., Kruta, I. \& MAPES, R.H. (eds) Ammonoid paleobiology, Volume II: from macroevolution to paleogeography. Topics in Geobiology 44 ..

KRÖGER, B. 2005. Adaptive evolution in Paleozoic coiled cephalopods. Paleobiology 31, 253-268. DOI 10.1666/0094-8373(2005)031[0253:AEIPCC]2.0.CO;2

KRÖGER, B. 2011. Size matters - Analysis of shell repair scars in endocerid cephalopods. Fossil Record 14, 109-118. DOI 10.5194/fr-14-109-2011

KrÖGER, B., Vinther, J. \& Fuchs, D. 2011. Cephalopod origin and evolution: a congruent picture emerging from fossils, development and molecules. Bioessays 33, 602-613. DOI 10.1002/bies.201100001

Kruta, I. \& Tanabe, K. 2015. Ammonoid radula, 539-552. In Klug, C., Korn, D., De Baets, K., Kruta, I. \& Mapes, R.H. (eds) Ammonoid paleobiology. I: From anatomy to ecology, Topics in Geobiology 43.

LAMSDELl, J.C. \& BRADDY, S.J. 2010. Cope's Rule and Romer's theory: patterns of diversity and gigantism in eurypterids and Palaeozoic vertebrates. Biology Letters 23, 265-269. DOI 10.1098/rsbl.2009.0700

LEgG, D.A. \& S. PAtes, S. 2016. A restudy of Utahcaris orion (Euarthropoda) from the Spence Shale (Middle Cambrian, Utah, USA). Geological Magazine 154, 1-6. DOI 10.1017/S0016756816000789

Lemche, H. \& Wingstrand, K.G. 1959. The anatomy of Neopilina galatheae Lemche, 1957 (Mollusca, Tryblidiacea). Galathea Report 3, 9-73.

Liow, L.H., ReITAN, T. \& HARNiK, P.G. 2015. Ecological interactions on macroevolutionary time scales: clams and brachiopods are more than ships that pass in the night. Ecology Letters 18, 1030-1039. DOI 10.1111/ele.12485

Long, J.A., Large, R.R., LeE, M.S.Y., Benton, M.J., Danyushevsky, L.V., ChiapPe, L.M., Halpin, J.A., CANTRILl, D. \& LotTermoser, B. 2016. Severe selenium depletion in the Phanerozoic oceans as a factor in three global mass extinction events. Gondwana Research 36, 209-218. DOI 10.1016/j.gr.2015.10.001

Lu, P.J., Yogo, M. \& Marshall, C.R. 2006. Phanerozoic marine biodiversity dynamics in light of the incompleteness of the fossil record. PNAS 103, 2736-2739. DOI 10.1073/pnas.0511083103

MaLlat, J. 1996. Ventilation and the origin of jawed vertebrates: a new mouth. Zoological Journal of the Linnean Society 117, 329-404. DOI 10.1111/j.1096-3642.1996.tb01658.x

MAPES, R.H. 1987. Upper Paleozoic cephalopod mandibles: frequency of occurrence, modes of preservation, and paleoecological implications. Journal of Paleontology 61, 521-538. DOI 10.1017/S0022336000028687

Martínez-Pérez, C., Rayfield, E.J., Botella, H. \& Donoghue, P.C. 2016. Translating taxonomy into the evolution of cono- dont feeding ecology. Geology 44, 247-250.

DOI 10.1130/G37547.1

Matern, H. 1931. Oberdevon Anaptychen in situ und über die Erhaltung von Chitin-Substanzen. Senckenbergiana 13, $160-167$.

McGHeE, G.R. JR. 2014. When the invasion of land failed. The legacy of the Devonian extinctions. 317 pp. Columbia University Press, New York.

McGhee, G.R. JR., Clapham, M.E., Sheehan, P.M., Bottjer, D.J. \& Droser, M.L. 2013. A new ecological-severity ranking of major Phanerozoic biodiversity crises. Palaeogeography, Palaeoclimatology, Palaeoecology 370, 260-270. DOI 10.1016/j.palaeo.2012.12.019

MeHL, J. 1984. Radula and arms of Michelinoceras sp. from the Silurian of Bohemia. Paläontologische Zeitschrift 58, 211-229. DOI 10.1007/BF02986061

Miserez, A., Schneberk, T., Sun, C., Zok, F.W. \& Waite, J.H. 2008. The transition from stiff to compliant materials in squid beaks. Science 319, 1816-1819.

DOI 10.1126/science. 1154117

MissarZHeVsKiJ, V.V. 1973. Konodontoobraznye organizmy iz pogranichnykh sloev kembriya i dokembriya Sibirskoj platformy i Kazakhstana [Conodont-shaped organisms from the Precambrian-Cambrian boundary beds of the Siberian Platform and Kazakhstan], 53-57. In Zhuravleva, I.T. (ed.) Problemy paleontologii $i$ biostratigrafii nizhnego kembriya Sibiri i Dal'nego vostoka. Trudy Instituta Geologii i Geofiziki SO AN SSSR 49. [in Russian]

Monnet, C., Klug, C. \& De Baets, K. 2011. Parallel evolution controlled by adaptation and covariation in ammonoid cephalopods. BMC Evolutionary Biology 11, 1-21. DOI 10.1186/1471-2148-11-115

Murdock, D.J., Dong, X.P., Repetski, J.E., Marone, F., Stampanoni, M. \& Donoghue, P.C. 2013. The origin of conodonts and of vertebrate mineralized skeletons. Nature 502, 546-549. DOI 10.1038/nature12645

Naglik, C., Tajika, A., Chamberlain, J. \& Klug, C. 2015. Ammonoid locomotion, 657-696. In KLUG, C., Korn, D., DE BAEtS, K., Kruta, I. \& MAPES, R.H. (eds) Ammonoid paleobiology, Volume I: from anatomy to ecology. Topics in Geobiology 43.

NEDIN, C. 1999. Anomalocaris predation on nonmineralized and mineralized trilobites. Geology 27, 987-990. DOI 10.1130/0091-7613(1999)027<0987:APONAM>2.3.CO;2

NÜTZEL, A. \& FRÝDA, J. 2003. Paleozoic plankton revolution: Evidence from early gastropod ontogeny. Geology 31, 829-831. DOI 10.1130/G19616.1

NütZel, A., LehNERT, O. \& FrÝdA, J. 2007. Origin of planktotrophy-evidence from early molluscs. Evolution and Development 9, 311-312.

PARRY, L., TANNER, A. \& Vinther, J. 2014. The origin of annelids. Palaeontology 57, 1091-1103. DOI 10.1111/pala.12129

Paxton, H. 2009. Phylogeny of Eunicida (Annelida) based on morphology of jaws. Zoosymposia 2.1, 241-264.

Payne, J.L., Heim, N.A., Knope, M.L. \& McClain, C.R. 2014. Metabolic dominance of bivalves predates brachiopod diver- 
sity decline by more than 150 million years. Proceedings of the Royal Society B 281, 1-8. DOI 10.1098/rspb.2013.3122

PORTER, S.M. 2016. Tiny vampires in ancient seas: evidence for predation via perforation in fossils from the 780-740 million-year-old Chuar Group, Grand Canyon, USA. Proceedings of the Royal Society B 283, 1-6. DOI 10.1098/rspb.2016.0221

ReIch, M. \& Sмith, A.B. 2009. Origins and biomechanical evolution of teeth in echinoids and their relatives. Palaeontology 52 , 1149-1168. DOI 10.1111/j.1475-4983.2009.00900.x

Rigby, S. \& Milsom, C.V. 2000: Origins, evolution, and diversification of zooplankton. Annual Review of Ecology and Systematics 31, 293-313. DOI 10.1146/annurev.ecolsys.31.1.293

Ritterbush, K.,Hoffmann, R., Lukeneder, A. \& De Baets, K. 2014. Pelagic Palaeoecology: the importance of recent constraints on ammonoid palaeobiology and life history. Journal of Zoology 292, 229-241. DOI 10.1111/jzo.12118

Roopnarine, P.D. 2010. Graphs, networks, extinction and paleocommunity food webs. Nature Precedings. https://core.ac.uk/download/pdf/289133.pdf

Rücklin, M., Donoghue, P.C.J., Johanson, Z., Trinajstic, K., Marone, F. \& Stampanoni, M. 2012. Development of teeth and jaws in the earliest jawed vertebrates. Nature 491, 748-751. DOI 10.1038/nature11555

SAnsom, I.J. \& SMith, M.M. 2001. The Ordovician radiation of vertebrates, 156-171. In AhLBERG, E. (ed.) Major events in vertebrate evolution. Taylor \& Francis, London.

SCHILLING, T. 2003. Making jaws. Heredity 90, 3-5. DOI 10.1038/sj.hdy.6800205

Schopf, J.W., Kudryavtsev, A.B., Czaja, A.D. \& Tripathi, A.B. 2007. Evidence of Archean life: Stromatolites and microfossils. Precambrian Research 158, 141-155. DOI 10.1016/j.precamres.2007.04.009

Seilacher, A. 1999. Biomat-related lifestyles in the Precambrian. Palaios 14, 86-93. DOI 10.2307/3515363

SeIlacher, A. \& Pflüger, F. 1994. From biomats to benthic agriculture: A biohistoric revolution, 97-105. In KRUMBEIN, W.E., Peterson, D.M. \& Stal, L.J. (eds) Biostabilization of Sediments. Carl von Ossietzky Universität Oldenburg, Oldenburg.

Seilacher, A., GraZhdankin, D. \& Legouta, A. 2003. Ediacaran biota: The dawn of animal life in the shadow of giant protists. Paleontological Research 7, 43-54. DOI 10.2517/prpsj.7.43

SePKoski, J.J. JR. 1978. A kinetic model of Phanerozoic taxonomic diversity I. Analysis of marine orders. Paleobiology 4, 223-251. DOI 10.1017/S0094837300005972

SePkoski, J.J. JR. 1984. A kinetic model of Phanerozoic taxonomic diversity III. Post-Paleozoic families and mass extinctions. Paleobiology 10, 246-267. DOI $10.1017 /$ S0094837300008186

SePkoski, J.J. JR. 2002. The compendium, 10-560. In JABLONSKI, D. \& Foote, M. (eds) A compendium of fossil marine animal genera. Bulletins of American Paleontology 363.

Servais, T., Harper, D.A.T., Li, J., Munnecke, A., Owen, A. \& SheEhan, P.M. 2009. Understanding the Great Ordovician Biodiversification Event (GOBE): Influences of paleogeography, palaeoclimate, or paleoecology? GSA Today 19, 4-10. DOI 10.1130/GSATG37A.1
Servais, T., Lehnert, O., Li, J., Mullins, G.L., Munnecke, A., NütZel, A. \& Vecoli, M. 2008. The Ordovician Biodiversification: revolution in the oceanic trophic chain. Lethaia 41, 99-109. DOI 10.1111/j.1502-3931.2008.00115.x Servais, T., Perrier, V., Danelian, T., Klug, C., Martin, R., Munnecke, A., Nowak, H., Nützel, A., Vandenbroucke, T., William, M. \& Rasmussen, C.M.Ø. 2016. The onset of the 'Ordovician Plankton Revolution' in the late Cambrian. Palaeogeography, Palaeoclimatology, Palaeoecology 458, 12-28. DOI 10.1016/j.palaeo.2015.11.003

SignoR, P.W. \& BRETT, C.E. 1984. The mid-Paleozoic precursor to the Mesozoic marine revolution. Paleobiology 10, 229-245. DOI 10.1017/S0094837300008174

SignOR, P.W. \& LiPPS, J.H. 1982. Sampling bias, gradual extinction patterns and catastrophes in the fossil record. GSA Special Paper 190, 291-296. DOI 10.1130/SPE190-p291

Signor, P.W. \& Vermeij, G. 1994. The plankton and the benthos: origins and early history of an evolving relationship. Paleobiology 20, 297-319.

DOI 10.1017/S0094837300012793

Smith, A.B., Lloyd, G.T. \& McGowan, A.J. 2012. Phanerozoic marine diversity: rock record modelling provides an independent test of large-scale trends. Proceedings of the Royal Society B 279, 4489-4495. DOI 10.1098/rspb.2012.1793

Smith, A.B., Reich, M. \& Zamora, S. 2013. Morphology and ecological setting of the basal echinoid genus Rhenechinus from the early Devonian of Spain and Germany. Acta Palaeontologica Polonica 58, 751-762.

StANLEY, S.M. 2007. An analysis of the history of marine animal diversity. Paleobiology 33, 1-55. DOI 10.1017/S0094837300019217

Tanabe, K., Kruta, I. \& Landman, N.H. 2015. Ammonoid buccal mass and jaw apparatus, 429-484. In KLUG, C., KorN, D., De Baets, K., Kruta, I. \& Mapes, R.H. (eds) Ammonoid paleobiology, Volume I: from anatomy to ecology. Topics in Geobiology 43.

TetLie, O.E. 2007. Distribution and dispersal history of Eurypterida (Chelicerata). Palaeogeography, Palaeoclimatology, Palaeoecology 252, 557-574.

DOI 10.1016/j.palaeo.2007.05.011

Thayer, C.W. 1979. Biological bulldozers and the evolution of marine benthic communities. Science 203, 458-461.

DOI 10.1126/science.203.4379.458

Trauth, F. 1927-1936. Aptychenstudien, I-VII. Annalen des Naturhistorischen MuseumsWien 41 (1927), 171-259; 42 (1928), 171-259; 44 (1930), 329-411; 45 (1931), 17-136; 47 (1936), 127-145.

TUREK, V. 1978. Biological and stratigraphical significance of the Silurian nautiloid Aptychopsis. Lethaia 11, 127-138. DOI 10.1111/j.1502-3931.1978.tb01297.x

Uyeno, T.A. \& Clark, A.J. 2015. Muscle articulations: flexible jaw joints made of soft tissues. Integrative \& Comparative Biology 55, 193-204. DOI 10.1093/icb/icv023

Uyeno, T.A. \& KieR, W.M. 2005. Functional morphology of the cephalopod buccal mass: A novel joint type. Journal of Morphology 264, 211-222. DOI 10.1002/jmor.10330 
Uyeno, T.A. \& KiER, W.M. 2007. Electromyography of the buccal musculature of octopus (Octopus bimaculoides): a test of the function of the muscle articulation in support and movement. Journal of Experimental Biology 210, 118-128. DOI 10.1242/jeb.02600

Valentine, J.W. 1969. Patterns of taxonomic and ecological structure of the shelf benthos during Phanerozoic time. Palaeontology 12, 684-709.

Valentine, J.W., Jablonski, D. \& ERwin, D.H. 1999. Fossils, molecules and embryos: new perspectives on the Cambrian explosion. Development 126, 851-859.

Vannier, J., Steiner, M., Renvoisé, E., Hu, S.X. \& Casanova, J.P. 2007. Early Cambrian origin of modern food webs: evidence from predator arrow worms. Proceedings of the Royal Society B 274, 627-633. DOI 10.1098/rspb.2006.3761

Van Roy, P., Daley, A.C. \& BrigGS, D.E.G. 2015. Anomalocaridid trunk limb homology revealed by a giant filter-feeder with paired flaps. Nature 522, 77-80. DOI 10.1038/nature 14256

VermeIJ, G.J. 1977. The Mesozoic marine revolution: Evidence from snails, predators and grazers. Paleobiology 3, 245-258. DOI 10.1017/S0094837300005352

VeRMEIJ, G.J. 1987. Evolution and Escalation: An Ecological History of Life. 537 pp. Princeton University Press, Princeton.

VermeIJ, G.J. 1994. The evolutionary interaction among species: Selection, escalation, and coevolution. Annual Review of Ecology and Systematics 25, 219-236. DOI 10.1146/annurev.es.25.110194.001251

Vermeis, G.J. 2013. On escalation. Annual Review of Earth and Planetary Science 41, 1-19.

DOI 10.1146/annurev-earth-050212-124123

Vinther, J., Stein, M., Longrich, N.R. \& Harper, D.A.T. 2014. A suspension-feeding anomalocarid from the Early Cambrian. Nature 507, 496-497. DOI 10.1038/nature13010

Vortsepneva, E., Ivanov, D., PurschKe, G. \& Tzetlin, A. 2013.
Morphology of the jaw apparatus in 8 species of Patellogastropoda (Mollusca, Gastropoda) with special reference to Testudinalia tesulata (Lottiidae). Zoomorphology 132, 359-377. DOI 10.1007/s00435-013-0199-y

Vortsepneva, E., Ivanov, D., Purschke, G. \& Tzetlin, A. 2014. Fine morphology of the jaw apparatus of Puncturella noachina (Fissurellidae, Vetigastropoda). Journal of Morphology 275, 775-787. DOI 10.1002/jmor.20259

Wainwright, P.C., McGee, M.D., Longo, S.J. \& Hernandez, P.L. 2015. Origins, Innovations, and Diversification of Suction Feeding in Vertebrates. Integrative \& Comparative Biology 55, 134-145. DOI 10.1093/icb/icv026

Whittington, H.B. \& Briggs, D.E.G. 1985. The largest Cambrian animal, Anomalocaris, Burgess Shale, British Columbia. Philosophical Transactions of the Royal Society B 309, 569-609. DOI 10.1098/rstb.1985.0096

WiTMER, L.M. 1995. The extant phylogenetic bracket and the importance of reconstructing soft tissues in fossils, 19-33. In Thomason, J.J. (ed.) Functional morphology in vertebrate paleontology. Cambridge University Press, Cambridge.

ZeIDBERG, L. \& RoBinson, B.H. 2007. Invasive range expansion by the Humboldt squid, Dosidicus gigas, in the eastern North Pacific. PNAS 104, 12948-12950.

DOI 10.1073/pnas.0702043104

Zhu, M., Ahlberg, P.E., Pan, Z., Zhu, Y., Qiao, T., Zhao, W., JIA, W. \& LU, J. 2016. A Silurian maxillate placoderm illuminates jaw evolution. Science 354, 334-336. DOI 10.1126/science.aah3764

Zhu, M., Yu, X. \& Janvier, P. 1999. A primitive fossil fish sheds light on the origin of bony fishes. Nature 397, 607-610. DOI 10.1038/17594

Zhu, M., Zhao, W., Jia, L., Lu, J., Qiao, T. \& Qu, Q. 2009. The oldest articulated osteichthyan reveals mosaic gnathostome characters. Nature 458, 469-474. DOI 10.1038/nature07855 